\title{
Why Brazil is not ready for the Twenty-First Century Taxonomy: a zoological view
}

\author{
Sergio Ricardo Andena
}

Laboratório de Sistemática de Insetos, Departamento de Ciências Biológicas, Universidade Estadual de Feira de Santana, Feira de Santana, Bahia, Brazil.

\begin{abstract}
Taxonomy has suffered from a lack of funds, attracting fewer students, and has been considered by some a mere descriptive field, a second-class science. Many authors have extensively pointed out the urgency of increasing our knowledge of biodiversity. Recently, a movement integrating researchers, institutes, and collections arose for addressing the biodiversity crisis and raising the status of taxonomy to 'Big Science'. This article discusses some impediments that are preventing Brazil entering the new era of taxonomy.
\end{abstract}

Additional key words: biodiversity, collections, internet, species.

Resumo (Porque o Brasil não está pronto para a taxonomia do século XXI: uma visão zoológica) - A taxonomia tem sofrido com a falta de recursos, atraindo menos estudantes, e tem sido considerada por alguns uma área meramente descritiva, uma ciência de segunda classe. Muitos autores têm apontado exaustivamente a necessidade eminente de se aumentar o conhecimento sobre a biodiversidade. Recentemente, um movimento integrando pesquisadores, institutos e coleções surgiu para reagir contra esta crise na biodiversidade e elevar o status da taxonomia para o de 'Grande Ciência'. Este artigo discute alguns aspectos que estão impedindo o Brasil de entrar na nova era da taxonomia. Palavras-chave adicionais: biodiversidade, coleções, espécies, internet.

Since the publication of the New Systematics by Huxley (1940), who misunderstood the concepts of classical taxonomy and the emerging New Synthesis, taxonomy has been relegated to second-class science (Wheeler 2004); it has not been considered part of the modern biology and questioned, as if a descriptive field could be actual science. As pointed out by Wheeler (2008: 1):

\footnotetext{
"The epistemological bases of population genetics - an experimental biology - and of taxonomy - a historical and comparative but not experimental biology - are simply incompatible. To do either well, one simply cannot use a single approach to both. This is not to say that one is better or more important than the other. They are simply focused on very different aspects of biology and necessitate very different assumption, theories and methods."
}

The time spent by a taxonomist in such core tasks comparing detailed structures in type specimens, checking variation among populations, identifying species accumulated in collections, producing identification keys, and describing new species - is, in most cases, much longer than core tasks in other fields of biology. This amount of work usually results in extensive monographs and revisions that, consequently, have resulted in a relatively low number of publications and a reduced short-term impact. In contrast, agricultural, medical, or molecular fields, which are fashionable, exciting, and have resulted in many more publications, have had a higher impact. From this perspective, taxpayers want to see their

Corresponding author: sergioricardoandena@gmail.com

Corresponding editor: Alessandro Rapini

Submitted: 20 Aug. 2012; accepted: 17 Mar. 2013

First published: 18 July 2013; final version: 2 May 2014 money applied to research for the treatment of diseases, the control of agricultural pests, and development of vaccines, rather than in dead specimens deposited in a museum. The problem with systematics, including primary descriptive taxonomy devoted to new species and monographs of those previously classified, was never the obsolescence, but our failure to recognize its true importance (Wilson 2004).

Unfortunately, this perspective has also been that of funding agencies, which have extensively applied their funds to 'Modern Biology'. Recently, modern techniques in molecular biology used in applied fields have received the majority of funds. Professor Edward O. Wilson of Harvard University said in a conference in Washington D.C. that:

\footnotetext{
"molecular labs are not flooded with money because their data are better; molecular data are perceived to be better because they receive so much funding. That funding reflects, too, an association by technique with biomedicine, whose obscene levels of funding cast a long shadow on basic biology" (apud Wheeler 2008: 9).
}

Another point is that the number of publications and their impact factor - and, in Brazil, also the Qualis (the evaluation method for publication used by Brazilian funding agencies and graduate courses; see more at http://capes.gov.br/avaliacao/qualis) - have become the common currency in science, with better job opportunities being filled by those who are publishing rapidly. I believe that this is one of the reasons that students have migrated to modern fields in biology, leaving classical taxonomy bereft of researchers. However, the number of publications and their impact factor do not mean that taxonomy is a worse, unfashionable, or renegade field. Krell (2002), 
in his article arguing that the impact factor cannot be used for taxonomy, also pointed out that taxonomists are declining in number and, consequently, taxonomy does not follow the exponential curve of most sciences. In Brazil, Marques \& Lamas (2006) cited that the average age of taxonomists is between 45-50 years old, who graduated around 23 years ago, in 1980s, with a decrease of new specialists in 1990s.

Biodiversity crisis. The impact of human beings on the environment is evident, causing its destruction and, consequently, the extinction of species, as well as climate change. The approximately 1.7 million species described in the past 250 years is underestimated and our knowledge on the biodiversity is far from complete in tropical regions. Considering only insects, which represents about $60 \%$ (1 million species) of living organisms, it is estimated that 3-30 million species are still to be discovered and these numbers increase to 3.6 to 100 million species when the entire biota is considered (Wilson 2004). It is thanks mainly to taxonomists that we know the inventory of extant and extinct organisms and for this reason alone taxonomy should be considered important enough to be qualified as 'Big Science'. Besides, taxonomy is not only descriptive; it also includes identification and phylogenies (Knapp 2004).

For the taxonomic community, the "truth universally acknowledged" is that taxonomic data are essential to any solution to the biodiversity crisis, and thus, that our discipline must carefully consider how it will become an integral part of these solutions (Knapp 2008). Unfortunately, given the lack of new taxonomists, discovering the rest of the biota may take a few more centuries.

Recently, a movement called 'Taxonomy for the Twenty-First Century' arose to raise the status of taxonomy to that of a 'Big Science', integrating researchers, collections, libraries, and digitized data to accelerate research into biodiversity. Some of the programs addressing this topic are: Global Biodiversity Information Facility (GBIF - www.gbif.org) in the European Community, Planetary Biodiversity Inventory (PBI - www.nsf.org) and Assembling the tree of life (Atol - www.nsf.org) in United States, Programa de Pesquisa em Biodiversidade (PPBiohttp://ppbio.inpa.gov.br/; http://marte.museu-goeldi.br/ ppbio/ppbio15/; http://www.uefs.br/ppbio/index.html), Biota-FAPESP (www.biota.org.br), Sisbiota (www.cnpq.br/web/guest/sisbiota), Protax (www.cnpq.br/web/guest/protax) and Centro de Referência em Informação Ambiental (www.cria.org.br) in Brazil, the internet being the main way for sharing these information among researchers and general public.

The advances in technology in the past decades, especially in informatics, i.e. computers, operating systems, and the internet, were huge. The internet became the best and fastest way for gathering any kind of information, including news, music, cinema, art, and also science, but some points must be taken into account. Below, I discuss the problems that are preventing Brazil entering in the Twenty-first Century Taxonomy, focusing the zoology; solutions to accelerate the integration of biodiversity data are beyond the scope of this article.

\section{UNIVERSITIES, RESEARCH, AND RESEARCHERS}

The richest and most productive universities are located in developed countries, where biodiversity is low compared with most developing countries, especially in the Neotropics, where the highest diversity of species on Earth is supposed to be found, and the poorest and less productive universities are located. Most of the research in Brazil has been done in public universities (federal or state), which are totally free of fees for students, with at least one campus of a federal university in each Brazilian State.

Historically, there are more taxonomists, scientific collections, graduate courses, and resources in southeastern and southern regions of Brazil (called here Region 1), which have resulted in long-term research and research groups, and consequently, in many more publications than other regions: $70.64 \%$ and $13.94 \%$ of articles in zoology published by Brazilians are produced by researchers in southeastern and southern regions, respectively (Marques \& Lamas 2006). Such regions have experienced a high rate of anthropic action and most of their natural vegetation has vanished. On the other hand, publication in northeastern, mid-western, and northern regions (called here Region 2), where the most preserved biomes are located - except the caatinga, that covers most of the northeastern region - represents only 5.89\%, 5.08\%, and $4.65 \%$ of articles produced in Brazil, respectively (Marques \& Lamas 2006). The few articles published in these regions may be the result of fewer specialists working there (Brandão et al. 2000; Marinoni et al. 2006; Marques \& Lamas 2006).

The Northeast is the region with the lowest number of researchers and institutions that hold biological collections; also, it is the region most affected by anthropic actions and is less sampled (Brandão et al. 2000). This region has been relegated for centuries, possibly because of the incorrect assumption that the arid regions were poor in diversity, as cited by Ducke (1907: 73), in his article about the fauna of Hymenoptera:

\footnotetext{
"Aucune partie de l'immense territoire de la Republique du Brésil n'est moins connue, quant à la faune des insectes, que lês Etats delà côte Nord-Est, de Maranhâo jusqu'à Bahia. Les naturalistes et les collectionneurs qui parcourent le pays, donnent la préférence à la région amazonienne, avec sa fabuleuse variété d'espèces de papillons, ou aux Etats méridionaux, de Rio-grande-do-Sul à Espirito Santo, avec
} 
leur climat agréable aux Européens, leur facilité de communications et les mille autres avantages que le progrès accentué de ces Etats offre au voyageur. C'est ainsi que notre connaissance de la faune des Etats du Nord-Est, où la nature est beaucoup plus pauvre et où les difficultés de toute espèce pour le collectionneur sont beaucoup plus grandes que dans l'Amazonie ou dans le Sud, est restée presque stationnaire depuis um siècle."

[No part of the vast territory of the Republic of Brazil is less known about than the insect fauna, than the states throughout the northeast coast of Maranhão to Bahia. Naturalists and collectors across the country prefer the Amazon regions, with its fabulous variety of species of butterflies, or the southern states of Rio Grande do Sul to Espirito Santo, with its pleasant climate for Europeans, ease of communication and thousands of other benefits, that highlights the progress of these states to offer the traveler. So our knowledge of the fauna of the northeastern states, where nature is much poorer and where difficulties of all kinds for the collector is much greater than the Amazon or the South, has remained almost stationary for a century]

Marinoni et al. (2006) and Marques \& Lamas (2006) suggested scientific incentives for implementing collections, institutions, and mainly, hiring of new taxonomists in regions that lack such structure, although attracting professionals to less developed regions, with poor infrastructure, including health system, entertainment, education, and housing, has been difficult. Dr. Pedro Walfir, Chair of Graduate courses of Universidade Federal do Pará (UFPA) said at the ABC (Academia Brasileira de Ciências) conference: "We must attract graduates to study here. This is easier than bringing doctors, who are around 30 years old, usually married, with a family, from other regions" (Oswaldo-Cruz 2010, my translation). "The key to make jobs in the region more attractive is the financial advantages", said the Chair of Research and Graduate of UFPA Emmanuel Tourinho at the same conference. He proposed a strategy, offering an extra fellowship, in addition to the salary, to 5,000 researchers (Oswaldo-Cruz 2010, my translation). Financial incentives are already employed by Embrapa (Empresa Brasileira de Pesquisa Agropecuária) for those working in northern region.

Beyond such incentives, universities, especially in taxonomic field, must hire those professionals with a good production in science to ensure that they can raise or be associated with graduate courses. Graduate courses are essential to science policies in any knowledge field and are crucial to the country by continuously producing systematists to replace the older generations. Such courses are also required for their institutions, in streamlining areas of research, teaching, and extension programs, and must be guided by high quality professionals, resulting in medium and long-term gains (Marques \& Lamas 2006).

In the last evaluation of CAPES (the Brazilian funding agency that also regulates graduate courses), in 2010, a total of 16 graduate courses in Zoology and related fields (that included taxonomy/systematics in their scope) are located in Region 2, being only six qualified for forming $\mathrm{PhD}$ students. Also, they gained the worst grades ( 3 or 4 , in a scale of 1-7). On the other hand, in Region 1, amongst 24 graduate courses with the same scope, only two of them obtained grade 3 (not qualified for teaching $\mathrm{PhD}$ students) and nine, grade 4 . The remaining courses obtained grade 5 or 6 ; none of these graduate courses obtained grade 7 (Figure 1).

The lack of taxonomists and graduate courses in Region 2 reflects the difficulties in getting grants from funding agencies. The last call of the Protax (Taxonomic Research Program) promoted by the three main funding agencies in Brazil (CNPq, CAPES, and $\mathrm{MCT}$ ), provided around US\$ 9.5 million for projects and graduate and post-doctorate fellowships. A total of 103 projects were awarded, with an average of

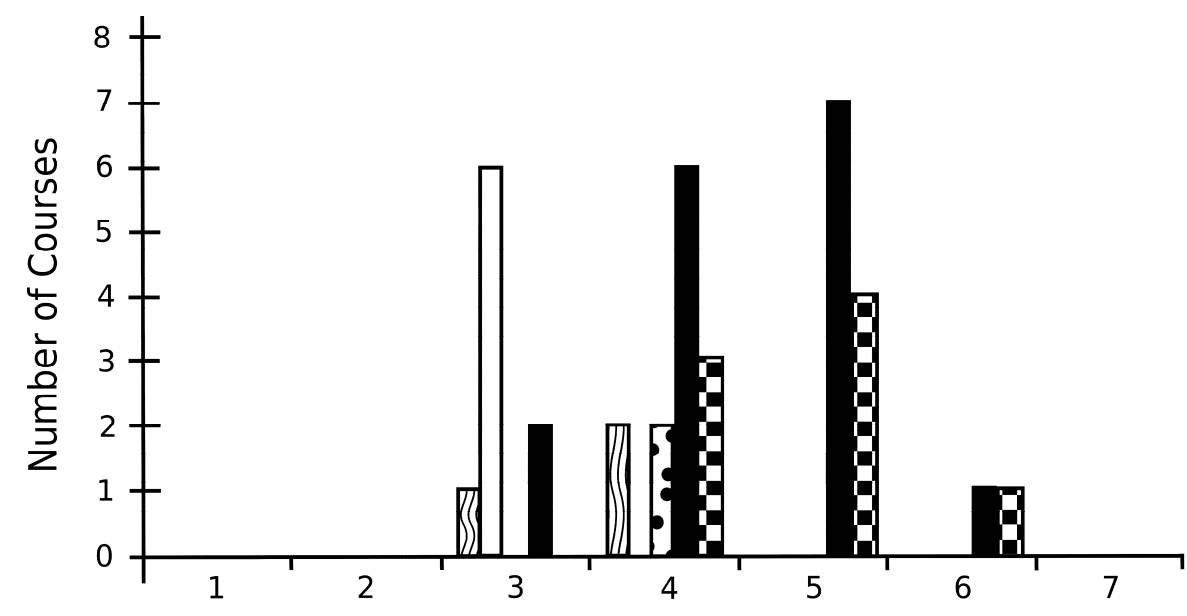

Grade

\section{[3] Northern $\square$ Northeastern Mid-Western Southeastern Southern}

Figure 1. Grades of Brazilian graduate courses in Zoology (and related fields), by region (Source: http://trienal.capes.gov.br/?page_id=100). 
US\$ 92,233 each. Of the total, 73 projects (70\%) were to research groups in Region 1 (Figure 2); in Zoology in particular, 47 projects were awarded, being 35 (74.4\%) to Region 1 (Figure 3).

\section{SPECIMENS, COLLECTIONS, AND INVENTORIES}

Taxonomy/systematics depends on specimens, which the majority are deposited in foreign collections. Brazil hosts about $20 \%$ of the planet's biodiversity, but this is represented by only $1 \%$ of the voucher material deposited in scientific collections worldwide (Fernandes 2006). Curators in Brazil use common practices, employed by researchers around the world, such as loans, exchange, and gifts of specimens among collections. Such practices are essential for any collection in increasing the number of species identified, obtaining representative material and for taxonomic studies. Unfortunately, Brazilian laws have restricted these practices, implementing rules for preventing biopiracy. Brazilian collections must be registered in the Ministry of Environment and any researcher or student, before going to the field, must ask for online permits (collecting and transportation) at Sisbio site (Sistema de Autorização e Informação em Biodiversidade: Authorization and Information System on Biodiversity), which may take months. For keeping permits activated, researchers must annually report the specimens collected in this system. Specimens collected should often be mailed to foreign specialists for identification, but due restrictions, this has become difficult. In some cases, such impediments are leaving
Brazilian taxonomists with no choice other than visiting foreign collections. This task is not so simple; it involves additional costs and time, and the small amount of funds available from foundations in the countries is insufficient in most cases. Certainly, such problems have been reflected in the low number of taxonomic revisions (Brandão et al. 2000).

The use of computers for an inventory is essential nowadays; however, software/hardware choice raises issues. Let me give an example: Microsoft Office, one of the most widely used suites in the world, has had many versions with different formats for saving documents. In 23 years, one of the components of this suite, Excel for Windows, had 13 versions launched; an average of one version per 1.76 year. The newest version of Microsoft Office has the option to save the file only from 2003 to present version. Specimens have been deposited in collections for centuries. Therefore, to make an inventory, we have to think centuries ahead. For instance, collections with advanced levels of inventories have often used barcode labels attached to the specimens. These labels save much time for filling out loan forms and for faster information searches in a collection. Despite the benefits of this system for collection management, in few years, they may represent a waste of time and money. Figure 4A shows the barcode commonly used and Figure 4B, the most recent barcode. Reading barcode labels depends on the software and, as shown above, they have changed rapidly. In few years, the current software will no longer be able to read barcodes presented in either format and the replacement of these labels may be onerous.

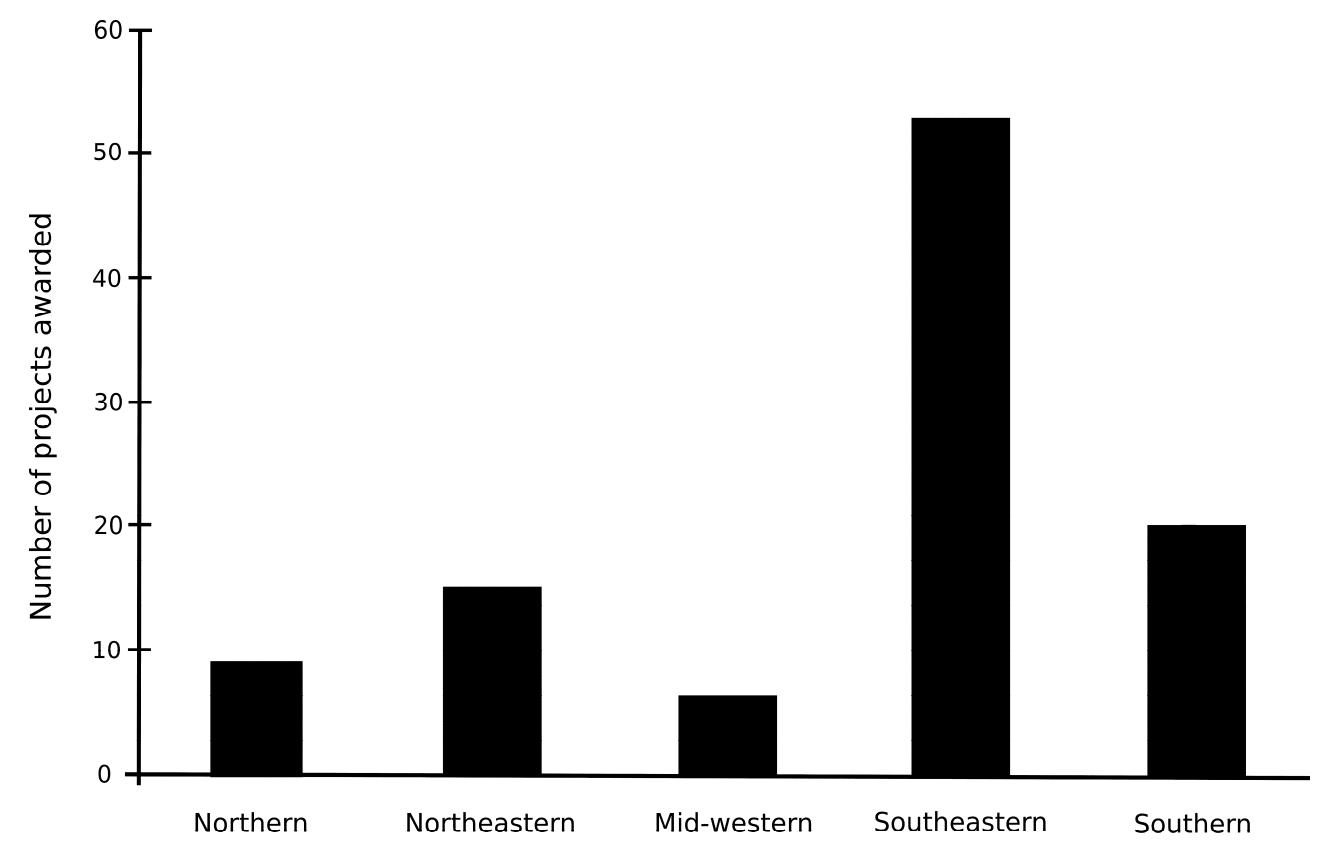

Figure 2. Protax Projects awarded in 2010, by region (Source: http://www.cnpq.br/web/guest/chamadas-publicas?p_p_id= resultadosportlet_WAR_resultadoscnpqportlet_INSTANCE_0ZaM\&idDivulgacao $=22 \&$ filtro $=$ resultados\&detalha $=$ chamadaDetalhada\&exi be $=$ exibe \&id $=47-89-1196 \&$ idResultado=47-89-1196). 


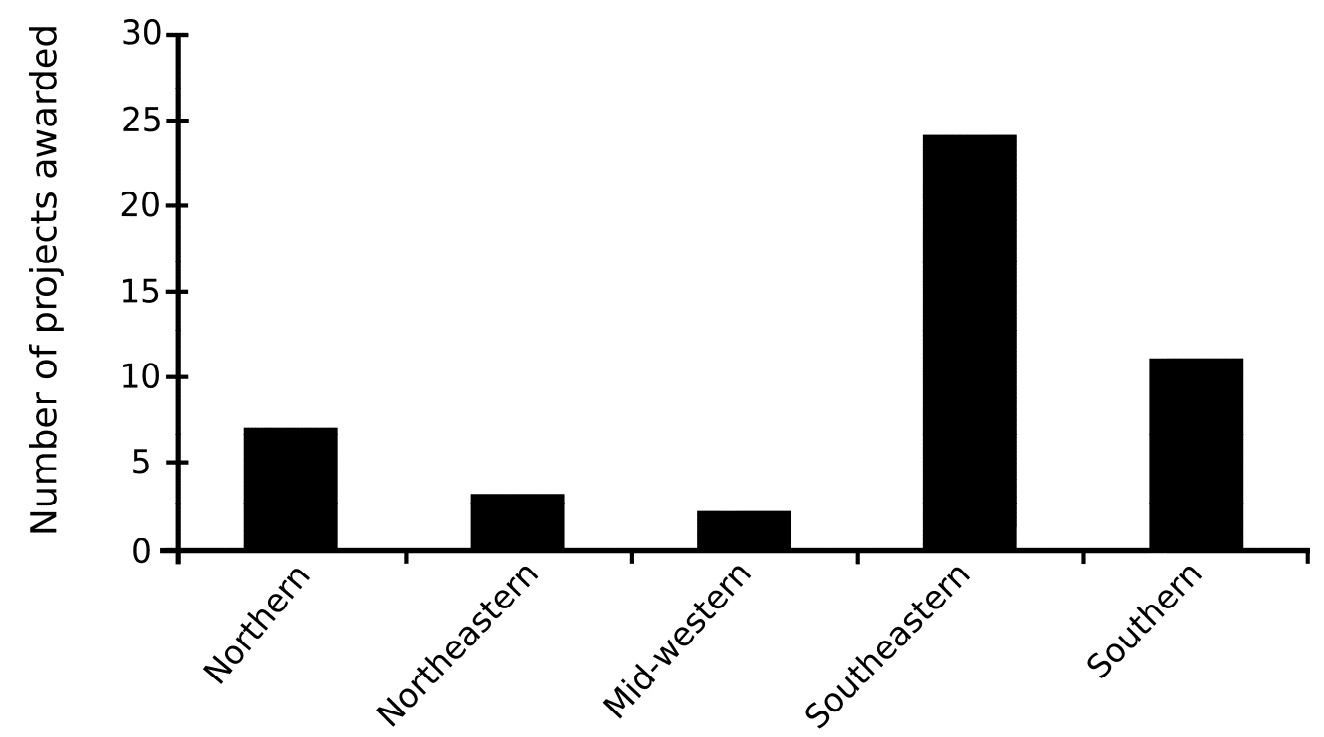

Figure 3. Protax Projects in zoology awarded in 2010, by region (Source: http://www.cnpq.br/web/guest/chamadaspublicas?p_p_id=resultadosportlet_WAR_resultadoscnpqportlet_INSTANCE_0ZaM\&idDivulgacao $=22 \&$ filtro $=$ resultados\&detalha $=$ chamad aDetalhada\&exibe $=$ exibe $\&$ id $=47-89-1196 \&$ idResultado=47-89-1196)

\section{LITERATURE}

The science of taxonomy is totally dependent on 250 years of legacy literature (Minelli 2003), and comparing original taxonomic descriptions in this literature with specimens is critical for taxonomy (Speers \& Edwards 2008). Unfortunately, the taxonomic literature is scattered and there is no authoritative index to this vast resource (Speers \& Edwards 2008). In some regions of Brazil, the libraries are poor, scattered, with scanty resources for buying journals and/or basic books as well as hosting rare books, and with a small amount of digital data. In most cases, it is possible to use an interlibrary loan, but most libraries are not qualified for such a task and, if so, it may take a long time. Many journals have maintained their articles available for free, online (e.g., American Museum Novitates, and Revista Brasileira de Entomologia), and some websites offer predominantly historical literature (e.g., www.biodiversitylibrary.org). Also, in Brazil, the Portal de Periódicos CAPES (www.periodicos.capes.gov.br/) has offered free access for many journals for researchers. Such initiatives have provided easy access to taxonomic literature, using the internet as the main tool for sharing it.

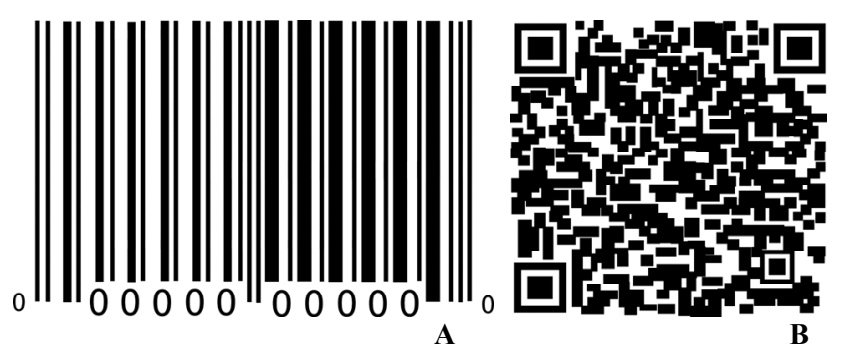

Figure 4. Barcodes: A- old and B- new formats.

\section{INTERNET}

The internet, as cited above, is the best and fastest way to share most kinds of information, and for science, it has been no different. The example of GBIF, creating a global data network, proves that it is possible to share information and certainly decreases differences between developed and developing countries. In Brazil, data networks have been working successfully in some projects, such as Biota-Fapesp, PPBio (Biodiversity Research Program) and Projeto Genoma Xylela (Fapesp). Also, as part of the strategies to raise the status of taxonomy in Brazil, some authors have reinforced the idea of networks (Brandão et al. 2000; Marinoni et al. 2006; Marques \& Lamas 2006). In spite of these efforts, Brazil does not have the same technology as developed countries do, and getting information on the World Wide Web may be complicated. First of all, the price of 'technology' in developing countries is higher, including hardware and software, decreasing the number of computers and software available for researchers and students. Second, broadband internet is often slower in Brazil compared with other countries (minimum of $250 \mathrm{KBs}$ in Brazil vs. minimum of $1,500 \mathrm{KBs}$ in USA) and, in some regions, it is completely absent, which is a problem for downloading high resolution photos, data, and literature from the internet. Third, the infrastructure for research in some universities is still substandard, including space and internet points for connection, aggravated in poor regions. In spite of some governmental efforts and the rapid increase of internet users (Avanços e Desafios dos Services Públicos On Line 2009), internet connections and 
computers are still not satisfactory for implementing a good data network in some regions.

To me, it does not make any sense to spend thousands of dollars on a data network, which could host literature, data, maps, and, what would be most important for taxonomists, photos of types, if several universities and institutions have unsatisfactory high speed internet connections. So, the increase in quality of internet is crucial for sharing information among taxonomists.

\section{Conclusion}

Compared with other megadiverse countries, biodiversity in Brazil is the highest, represented by about $20 \%$ of all described species (Marinoni et al. 2006), distributed in six main biomes (http://www.mma.gov.br/biomas). Brazilian biomes have suffered for centuries, since colonization, with the Atlantic Rain Forest being the most affected, with only about $7 \%$ of its well preserved original cover remaining (http://www.mma.gov.br/biomas/mataatlantica). The causes are many for the destruction and over-exploitation of these biomes: industrialization, uncontrolled growth of urban areas, real estate, predatory hunting and fishing, expansion of agriculture, etc. The knowledge of biodiversity is urgent and taxonomists are fundamental in providing and organizing this knowledge. Training qualified students and professionals employed in universities and institutes in areas with preserved environments and funding incentives are ways for achieving knowledge of Brazilian biodiversity.

Roma (pers. comm.), who is studying the history of Phylogenetic Systematics in Brazil, said that the Curso Especial em Sistemática Zoológica [Special Course on Zoological Systematics] was promoted from 1981 throughout 1984 in six editions (3-4 months each) in Instituto Nacional de Pesquisa da Amazônia (Manaus, Amazon State), Universidade Federal de São Carlos (São Carlos, São Paulo State), Universidade Federal da Paraíba (João Pessoa, Paraíba State), Universidade Federal de Juiz de Fora (Juiz de Fora, Minas Gerais State), and Universidade Federal do Pará (Belém, Pará State). It graduated 75 students/professionals, and also resulted in the creation of the Sociedade Brasileira de Zoologia. Roma's data matched with data cited by Marques \& Lamas (2006): most taxonomists in Brazil graduated in the 1980s. Unfortunately, few documents of the Curso Especial em Sistemática Zoológica remain (Roma, pers. comm.), but the course assisted the progress of the zoological systematics in Brazil and the training of the systematists who are currently working in the country. Similarly, the Willi Hennig Society has also promoted workshops around the world for theory and practice of phylogenetic systematics, including Brazil, where such workshops have been conducted at UNESP, São José do Rio Preto (São
Paulo State), in five editions (from 2008 to 2012) (Noll, pers. comm.). The re-launching of the Curso Especial em Sistemática Zoológica, and the promoting of the Willi Hennig Workshop, in other regions of Brazil would help to raise new teams of systematists, especially in regions that currently lack such professionals.

Actions for attracting doctor researchers, especially in taxonomy, to less developing regions are urgent and universities should seriously consider this topic. Similar actions were applied around 30 years ago at the Universidade Estadual de Campinas (UNICAMP, Campinas, São Paulo State) and Universidade de São Paulo (USP-Ribeirão Preto, São Paulo State), including the hiring of foreign doctors. Nowadays, we can see the results of such actions, since these universities are amongst the best of Brazil. Unfortunately, the lack of taxonomists and resources in some regions of Brazil is causing a circular problem: few taxonomists publish less and do not get grants. They cannot be associated with graduate courses and do not train students. This result, again, in few taxonomists, who will publish less... and over and over.

The restricting Brazilian legislation should be changed for researchers, curators, and students. It has caused delay in research, especially for graduate students, whose projects have a tight time for fieldwork, and also for Brazilian collections, which are becoming less representative and consequently more dependent of foreign collection.

Page (2006) showed that the support provided by NSF (National Science Foundation) to the Catfish project substantially increased the number of publications, the description of new species, training expertise, and producing a data network for researchers around the world. Despite the recent increasing of funding programs addressing taxonomy in Brazil, the investment is not yet sufficient and its distribution among regions is unequal, as shown for Protax.

Marques \& Lamas (2006) proposed actions that should be reached by 2015, which would certainly help Brazil reach the Twenty-first Century Taxonomy. Unfortunately, they are still far from the goal. Here, I have highlighted some of these topics that were not reached yet: 1- publication, in internet, of 100 catalogs about different zoological taxa; 2- publication of 30 textbooks about different zoological taxa (most restricted groups); 3- substantial increase of zoological collections, with a network for their national integration; 4- all graduate programs must have at least grade 4 or preferably grade 5 (CAPES grades); and 5installation of 100 new professors in deprived areas of systematics in the country, reaching the goal of no need for systematists in any State.

Despite advances, after 12 years since the publication by Brandão et al. (2000) and six years since Marinoni et al. (2006) and Marques \& Lamas (2006), taxonomy in Brazil maintains the same trends. 
Possible solutions for putting Brazil in the TwentyFirst Century Taxonomy have been proposed already, but few effective actions have been taken. I hope that this article alerts Brazilian taxonomists once again to the taxonomic crisis and encourages discussions about possible short-term solutions to establish the TwentyFirst Century Taxonomy in Brazil.

\section{ACKNOWLEDGEMENT}

I thank James Carpenter and Marcel Hermes, for critical review of an early version of this manuscript.

\section{REFERENCES}

Avanços e Desafios dos Serviços Públicos On Line 2009. Políticas públicas em foco. Boletim Fundap-Cebrap. Available at $<$ http://www.boletim-fundap.cebrap.org.br/n3/?subject=leituraindicadores-p1>; accessed in 3 Ago. 2012.

Brandão, C.R.F.; Cancello, E.M. \& Yamamoto, C.I. 2000. Avaliação do estado do conhecimento da diversidade biológica do Brasil. Invertebrados Terrestres - versão preliminar. Available at http://www.mma.gov.br/port/sbf/chm/doc/ invter1.pdf; accessed in 20 Ago. 2012.

Ducke, A. 1907. Connaissance de la faune Hyménoptérologique du nord-est du Brésil. Revue D'entomologique 26: 73-96.

Fernadens, L. 2006. Presentation. In: A.L. Peixoto, D.A.L. Canhos, L. Marinoni \& R. Vazoller (orgs), Diretrizes e Estratégias para a Modernização de Coleções Biológicas Brasileiras e a Consolidação de Sistemas Integrados de Informação sobre Biodiversidade. Centro de Gestão e Estudos Estratégicos/Ministério da Ciência e Tecnologia, Brasília, p. 183-211.

Huxley, J. 1940. The New Systematics. Oxford University Press, Oxford.

Knapp, S. 2004. Systematics: a science of three parts. Natural History Museum 4: 10-13.

Knapp, S. 2008.Taxonomy as a team sport. In: Q.D. Wheeler (ed.), The New Taxonomy. The systematic association special volume series 76. CRC Press, Taylor and Francis Group, Boca Raton, p. 33-54

Krell, F.T. 2002. Why impact factors don't work for taxonomy. Nature 415: 957.
Marinoni, L.; Magalhães, C. \& Marques, A.C. 2006. Propostas de estratégias e ações para a consolidação das coleções zoológicas brasileiras. In: A.L. Peixoto, D.A.L. Canhos, L. Marinoni \& R. Vazoller (orgs), Diretrizes e Estratégias para a Modernização de Coleções Biológicas Brasileiras e a Consolidação de Sistemas Integrados de Informação sobre Biodiversidade. Centro de Gestão e Estudos Estratégicos/Ministério da Ciência e Tecnologia, Brasília, p. 183-211.

Marques, A.C. \& Lamas, C.J.E. 2006. Taxonomia zoológica no Brasil: estado da arte, expectativas e sugestões de ações futuras. Papéis Avulsos de Zoologia 46(13): 139-174.

Minelli, A. 2003. The status of taxonomic literature. Trends in Ecology and Evolution 18: 75-76.

Oswaldo-Cruz, E. 2010. Atração e fixação de doutores na região amazônica. Academia Brasileira de Ciências Homepage. Available at http://www.abc.org.br/article.php3?id_article=703; accessed in 20 Ago. 2012.

Page, L.M. 2006. Planetary biodiversity inventories: a response to the taxonomic crisis. Action Bioscience E-Newsletter. American Institute of Biological Science. Available at $<$ http://www. actionbioscience.org/biodiversity/page.html>; accessed in 31 Oct. 2012.

Speers, L. 2005. E-types-a new resource for taxonomic research. In: C.L. Häuser, A. Steiner, J. Holstein \& M.J. Scoble (eds), Digital Imaging of Biological Type Specimens, a Manual of Best Practice. Results from a study of the European Network for Biodiversity Information. Staatliches Museum für Naturkunde, Stuttgard, p. 13-18.

Speers, L \& Edwards, J.L. 2008. International infrastructure for enabling the new taxonomy: the role of the global biodiversity information facility (GBIF). In: Q.D. Wheeler (ed.), The New Taxonomy. The systematic association special volume series 76 . CRC Press, Taylor and Francis Group, Boca Raton, p. 87-94.

Wheeler, Q.D. 2004. Taxonomic triage and the poverty of phylogeny. Philosophical Transactions of the Royal Society 359: 571-583.

Wheeler, Q.D. 2008. Introduction: toward the new taxonomy. In: Q.D. Wheeler (ed.), The New Taxonomy. The systematics association special volume series 76. CRC Press, Taylor and Francis Group, Boca Raton, p. 1-18.

Wilson, E.O. 2004. The meaning of biodiversity and the tree of life. In: J. Cracraft \& M.J. Donoghue (eds), Assembling the Tree of Life. Oxford University Press, New York, p. 539-542p. 